\title{
Integrating Business Sustainability, Corporate Governance and Organization Ethics into Business and Accounting \\ Curricula Panel - 666,
}

MODERATOR: ZABIHOLLAH (ZABI) REZAEE

Thompson-Hill Chair of Excellence and Professor of Accounting

Fogelman College of Business and Economics

The University of Memphis

Presenters/Panelists:

Damon Fleming, Dean of Fogelman College of Business and Economics, The University of Memphis

Sri Ramamoorti, Professor of Accounting at University of Dayton,

Robert Hirth, Vice Chair of the Sustainability Accounting Standards Board (SASB)

Brigitte MuehImann, Professor of Accounting at Babson College

Timothy Fogarty, Professor of Accounting at Case Western Reserve University

2020 AAA Virtual Annual Meeting, August 12, 2020 at 5:00-6:00 pm 


\section{INTRODUCTION}

Business sustainability, corporate governance and organizational ethics are taking center stage in the global business environment.

The AACSB standards now require "Business Sustainability, Corporate Governance, and Organizational Ethics" education for business schools starting January 2019.

Business sustainability is now being integrated into corporate culture and strategic decisions because sustainability performance information is demanded by investors, required by global regulators, more than 45000 business organizations are now disclosing sustainability information worldwide.

Sustainability is also integrated into all disciplines in business colleges from management, accounting, supply chain, marketing, economics, finance and BIT and more than 450 business programs offer a stand-alone business sustainability course. Corporate governance has been the main theme of the $21^{\text {st }}$ century and business sustainability is transforming from branding and greenwashing to a business strategic imperative.

Organizational ethics has been promoted in improving and promoting corporate culture of integrity, competency and accountability, preventing future financial scandals and crises and addressing challenges brought on by the COVID-19 pandemic. 
BUSINESS SUSTAINABILITY CORPORATE GOVERNANCE AND ORGANIZATIONAL ETHICS

Zabihollah Rezaee

with Timothy Fogarty

\section{Business Textbook}

- 30 chapters organized into four modules on Business Sustainability, Corporate Governance and Organizational Ethics.

-Addresses the latest revisions to the AACSB Accreditation Standards. 
Business sustainability is a process of creating shared value for all stakeholders and It is becoming a business imperative as shareholders demand, regulators require, and companies report their sustainability performance.

- Impact Investing: Companies Responses

- Tone at the Top: The Boardroom Conversation

- Executive Commitments

- Triple Bottom Line

- Planet, People and Profit (3Ps).

- Profit-with-Purpose

- "Where we go from here?" 


\section{Why}

\section{Demanded by investors}

More than 1,300 institutional investors worldwide, representing $\$ 59$ trillion in assets under management, have signed on to the U.N. Principles of Responsible Investing, which seek to integrate sustainability concerns into investment objectives.

\section{Reported by companies}

Now more than 15,000 global public companies disclose their Economic Sustainability Performance (ESP) and Environmental, Social and Governance (ESG) sustainability Performance.

\section{Mandated by regulators worldwide}

6,000 European Companies will be required to disclose ESG and diversity, in 2017. Hong Kong listed companies are now require to disclose both ESP and ESG (2016 and onwards). 


\section{Sustainability Framework}

- Definition: a process of achieving all five EGSEE dimensions of sustainability performance in creating shared value for all stakeholders by generating revenue for shareholders and protecting interests of other stakeholders.

- Create shared value for all stakeholders

- The main goal and objective function is to maximize firm value

- Time horizons

- Multidimensional nature of sustainability performance in all EGSEE areas

- Tensions among EGSEE 


\section{Shared Value Creation}

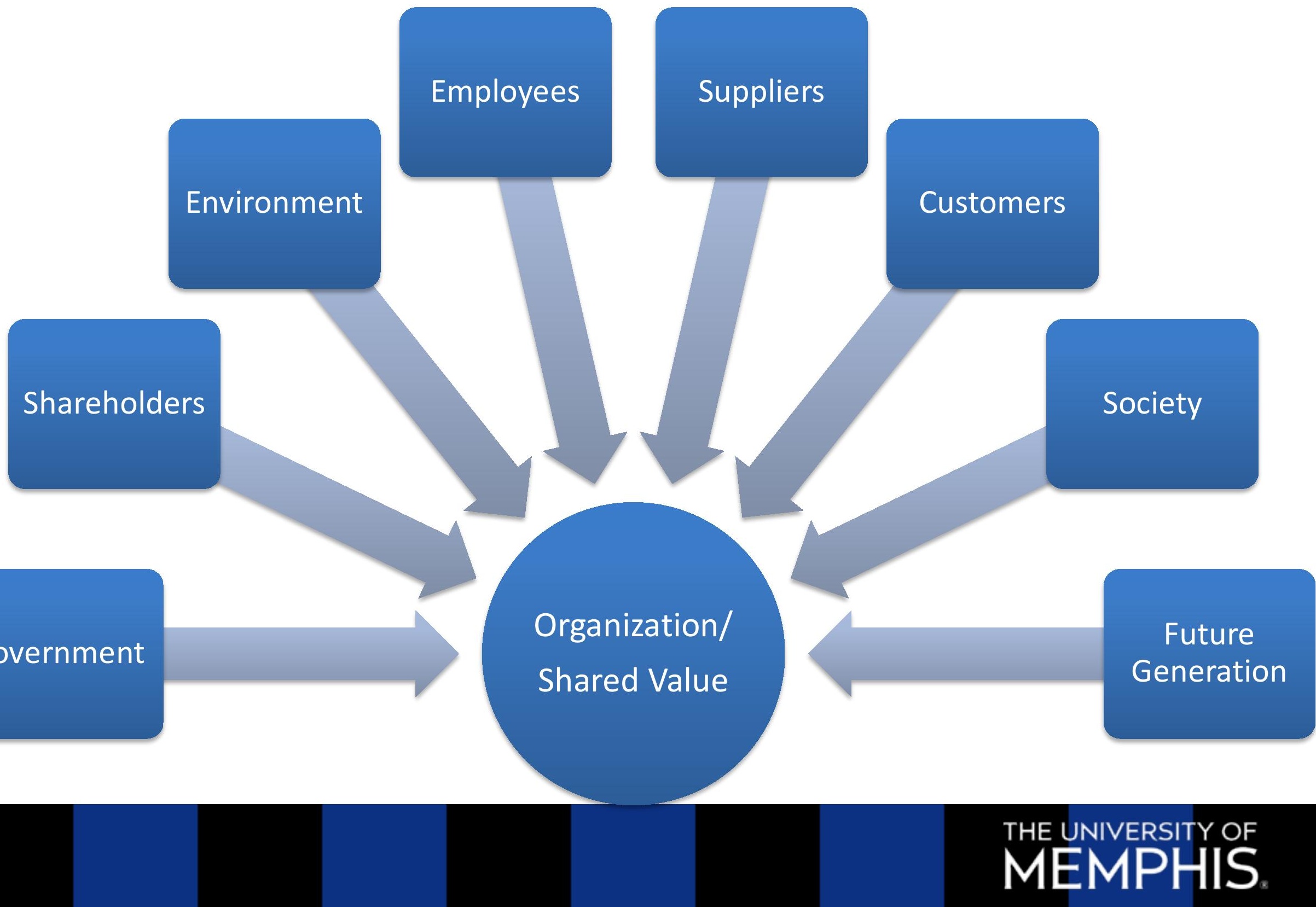




\section{Tension}

Economic

Sustainability

Performance

(ESP)
Environmental, Social and Governance (ESG)

Sustainability Performance 


\section{Entity Performance}

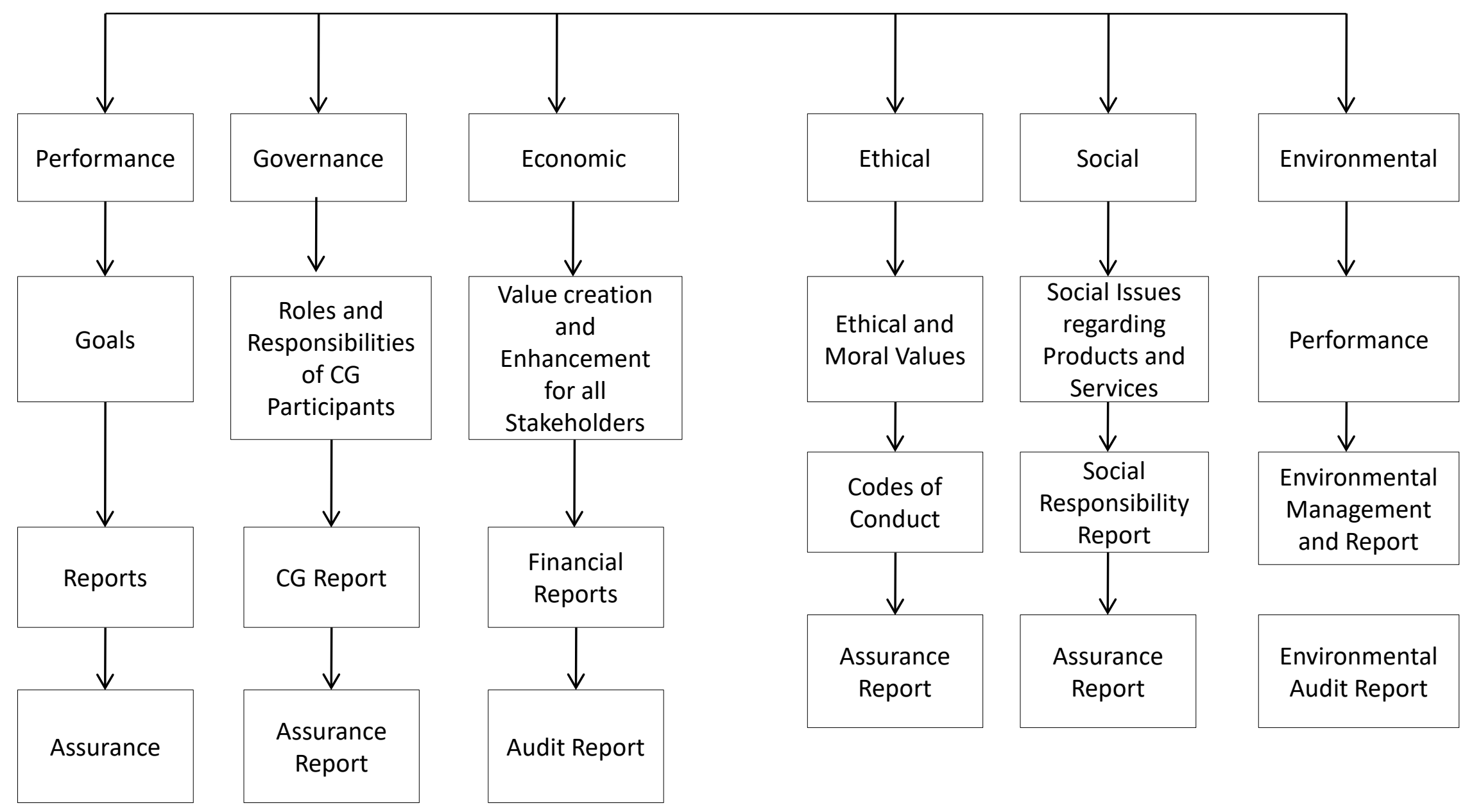




\section{Measuring Strategic Capital, Equity Capital, Intellectual}

Capital, Reputational Capital, and Environmental Capital

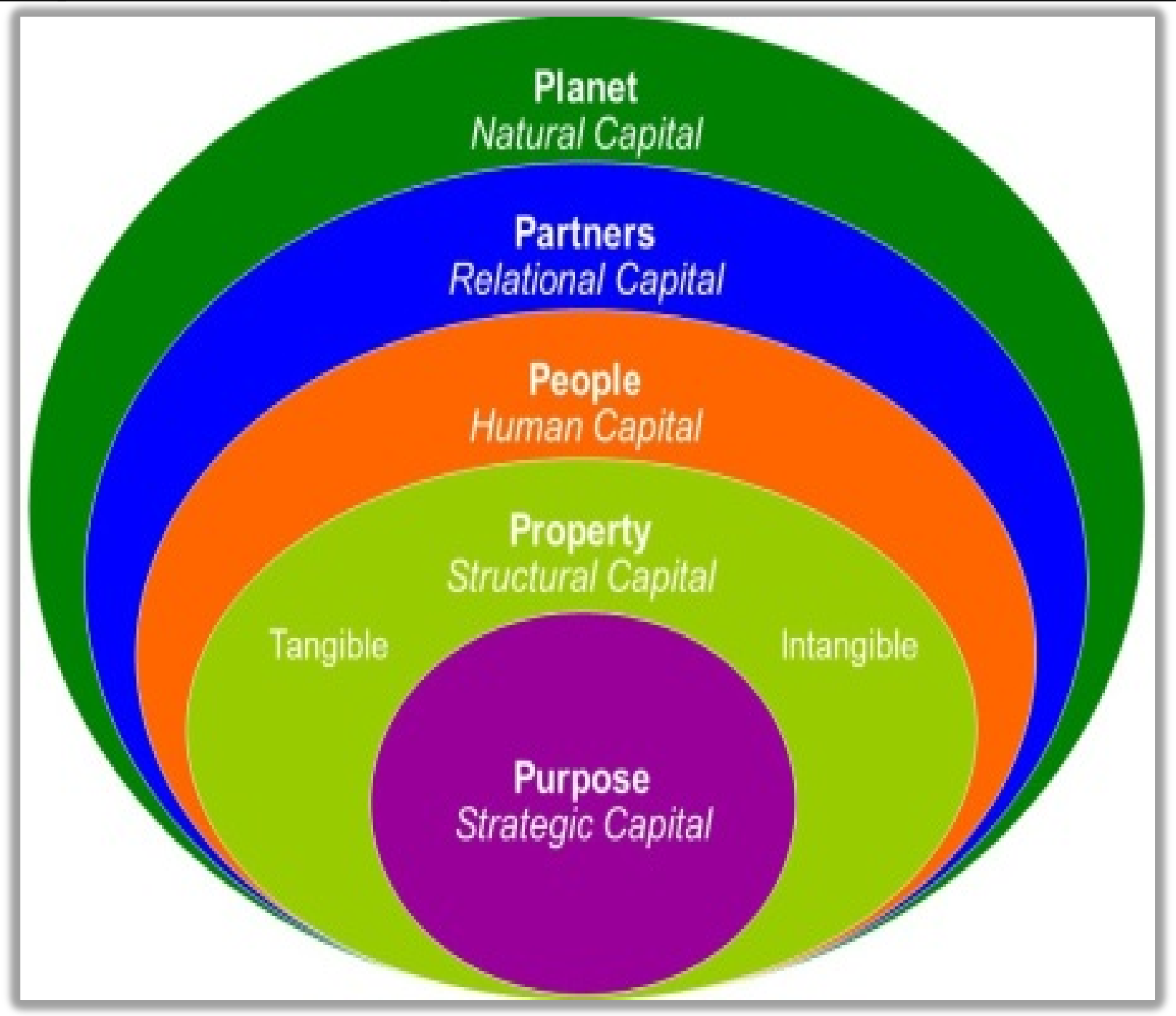

THE UNIVERSITY OF MEMPHIS. 


\section{Shareholder and}

\section{Stakeholder Primacy}

Shareholder Primacy Model

Corporations generate returns for

shareholders, and thus managerial

decisions and actions should be focused on creating shareholder value.

Stakeholder Primacy Model

Corporations create shared value for all stakeholders by securing financial returns for shareholder and making a positive contribution to society and the environment. 


\section{Profit with Purpose}

- Signed by 181 well-known, high-powered CEOs.

- Moves away from shareholder primacy-that corporations exist principally to serve shareholders"-

- Moves to stakeholder primacy: Americans deserve an economy that allows each person to succeed through hard work and creativity that will lead to a life of meaning and dignity.

- The free-market system is the best means of generating good jobs, a strong and sustainable economy, innovation, a healthy environment and economic opportunity for all.

- Businesses play a vital role in the economy by creating jobs, fostering innovation and providing essential goods and services. 


\section{Legislation}

- ESG Disclosure Simplification Act

- The Shareholder Protection Act

- Corporate Human Rights Risk Assessment, Prevention, and Mitigation Act of 2019

- Climate Risk Disclosure Act of 2019

- Accountable Capitalism Act of 2018

- SEC $10 \mathrm{~K}$ and other fillings 


\section{Best Practices of Sustainability}

1. Long-term Sustainability Investment Strategies: Individual investors as well as institutional investors should focus on long-term and sustainable investments rather than short-termism market movements.

2. Sustainability tone at the top in engaging in sustainability initiatives:

- First, socially responsible investors place in proxy proposals a need for the election of at least one director with sustainability interests and skills.

- Second, creation of a board sustainability committee consisting directors with adequate sustainability expertise.

- Third, the entire board of directors is being required to engage in sustainability issues and initiatives, being held accountable for achieving sustainability performance and to provide the needed sustainability leadership.

3. Executive Commitments for Promoting EGSEE Sustainability Performance:

- First active oversight function of the board of directors demanding sustainability performance from executives.

- Second, include a sustainability performance target clause in executive compensation contract.

- Third the labor market to reward sustainability executive leadership and punish managerial shorttermism.

4. Sustainability Investment initiatives and innovation.

5. Integration of sustainability performance reporting and assurance into corporate reporting. 


\section{Benefit Corporations}

Certified

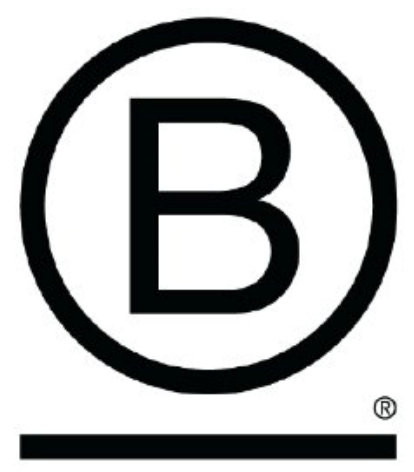

Corporation
- Benefit Corporations (BCs) are intended to fill a gap between traditional corporations and nonprofits by giving social entrepreneurs flexibility to achieve the dual objectives of doing well and doing good.

- The justification for BCs is that that existing law prevents boards of directors from considering the impact of corporate decisions on other stakeholders, the environment or society at large.

- Boards of directors of BCs are required to consider the impact of their decisions on specific corporate constituencies, including shareholders, employees, suppliers, the community, as well as on the local and global environment. 


\section{Sustainability Promoting Organizations}

Several Organizations are currently promoting sustainability including:

The Global Reporting Initiative (GRI), 2013G4 sustainability guidelines, promotes integrated reporting on the five EGSEE dimensions of sustainability performance with the ethical dimension being incorporated into other dimensions.

http://www.globalreporting.org/

The International Integrated Reporting Council (IIRC), in 2013 developed the International Integrated Reporting Framework

http://www.theiirc.org/consultationdraft2013

Sustainability Accounting Standards Board (SASB) is currently developing sustainability accounting standards intended to assist public companies in disclosing material sustainability issues for the purpose of mandatory filings to the SEC, such as the Form 10-K and 20-F through the first quarter of 2015.

\section{Corporate Reporting Dialogue}

- http://corporatereportingdialogue.com/ 


\section{Integrating sustainability to the Business Curriculum}

- Sustainability Education (SE) continues to increase

- More universities are planning to provide SE

- Numerous SE topics are considered important

- Methods of integration

- A stand-alone course in SE

- Infusion of SE topics into business courses

- Curriculum Implications of SE

- The AACSB Accreditation Standards require business school to cover "Business Sustainability, Corporate Governance and Organization Ethics education starting January 2019.

- More than 200 business school worldwide are delivering variation of business sustainability education. 


\section{Sustainability Research}

More than 150 Published papers on Corporate Social Responsibility (CSR) and Sustainability:

- Effects on Financial Reporting

- Effects on Earnings quality

- Effects on Cost of capital

- Effects on Tax avoidance

- Effects on Stock Prices

- Effects on Financial Performance

Two articles published in the Journal of Accounting Literature provide synthesis of research on CSR and Sustainability.

Rezaee, Z. 2016. Business Sustainability Research: A Theoretical and Integrated Perspective, Journal of Accounting Literature, 36 (2016): 48-64

Huang, X. B., \& Watson, L. (2015). Corporate social responsibility research in accounting. Journal of Accounting Literature, 34, 116. 


\section{Sustainability Integrated Approach}

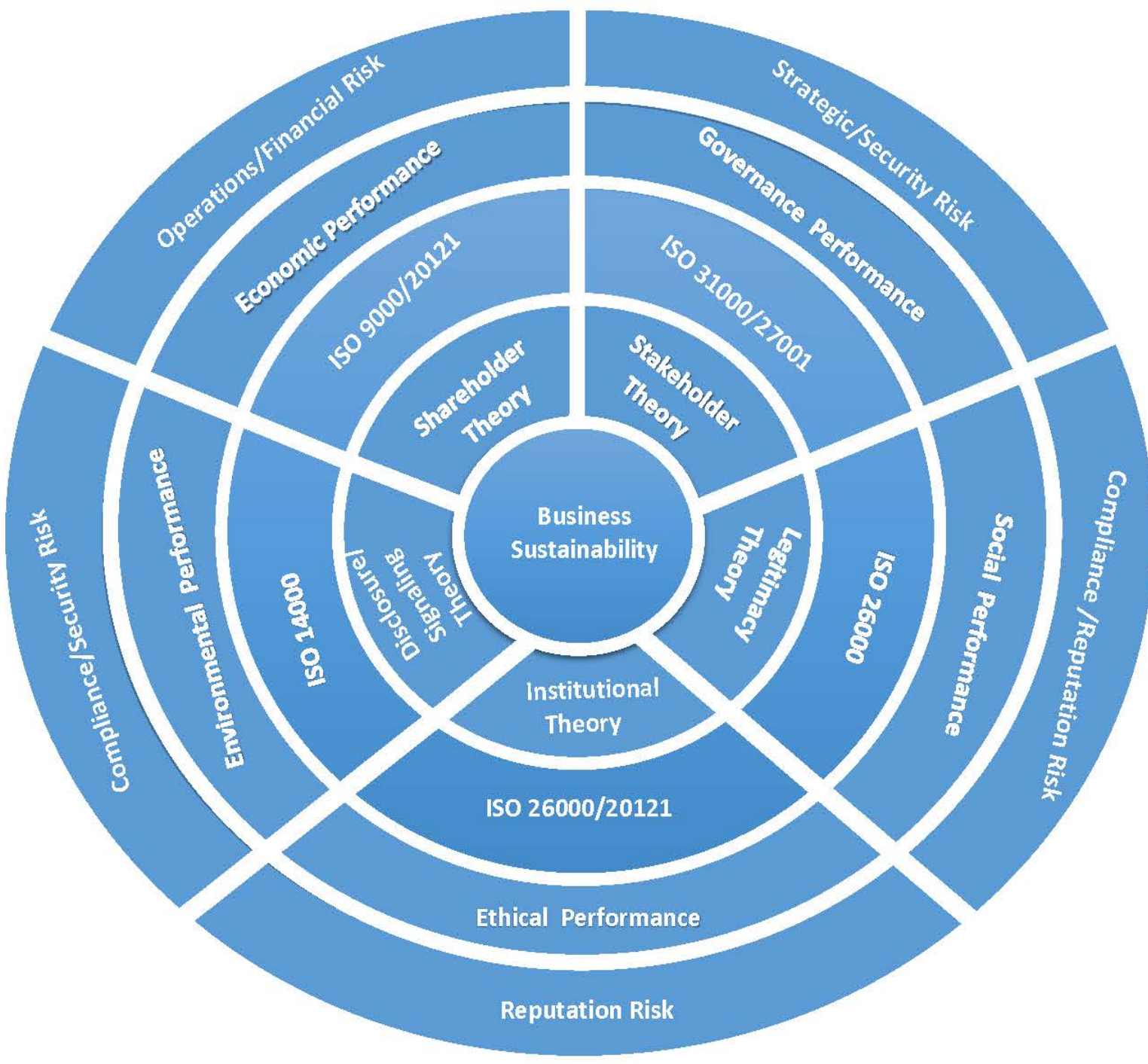

THE UNIVERSITY OF MEMPHIS. 


\section{Bottom-Line Earnings}

- Impact Investing

- Tone at the top

- Executive Commitments

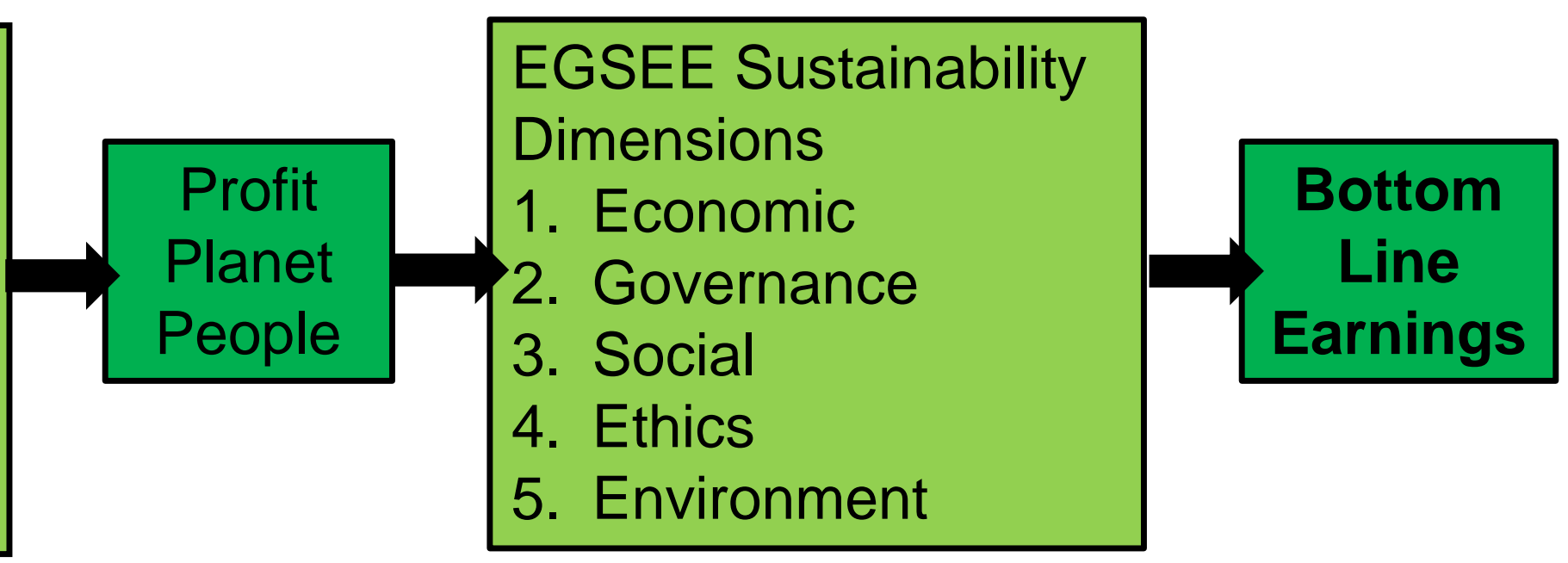




\section{Introduction to Corporate Governance}

- Corporate governance is defined as a process of managing and running an organization for the benefit of its stakeholders

- Effective corporate governance can only be achieved when all participants:

1. add value to the company's sustainable long-term performance;

2. effectively carry out their fiduciary duty and professional responsibilities;

3. are held accountable and personally responsible for their performance;

4. develop a practice of not only complying with applicable regulations, but also committing to doing the right thing and observing ethical principles of professional conduct in avoiding potential conflicts of interest. 


\section{Corporate Governance Structure}

- Corporate governance is based on three interrelated components: corporate governance principles, functions and mechanisms.

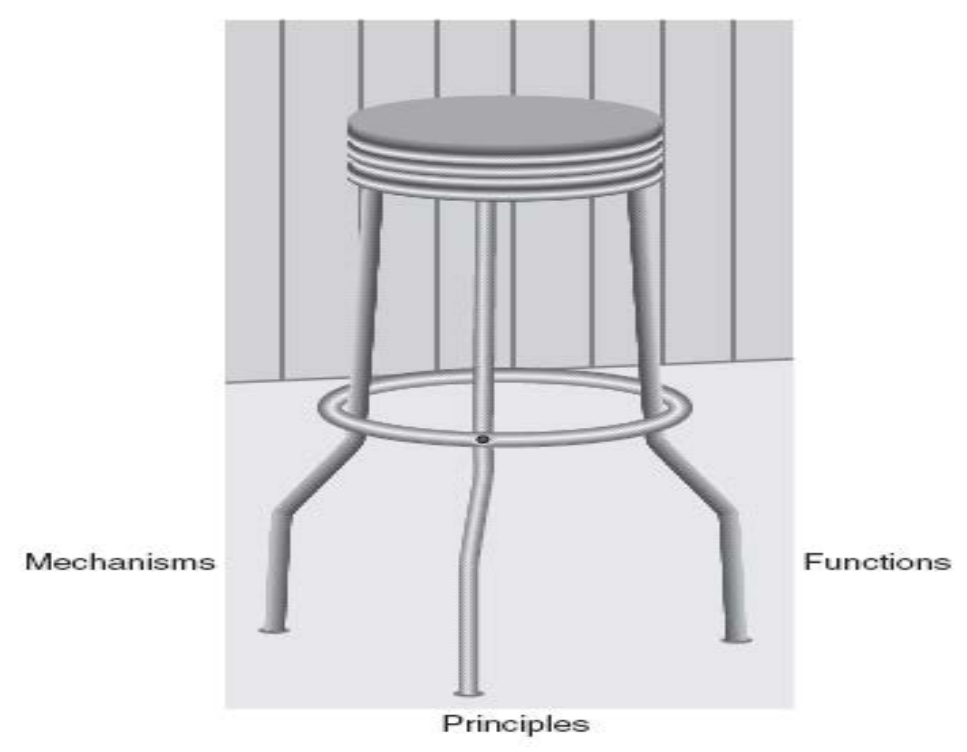




\section{Corporate Governance Functions}

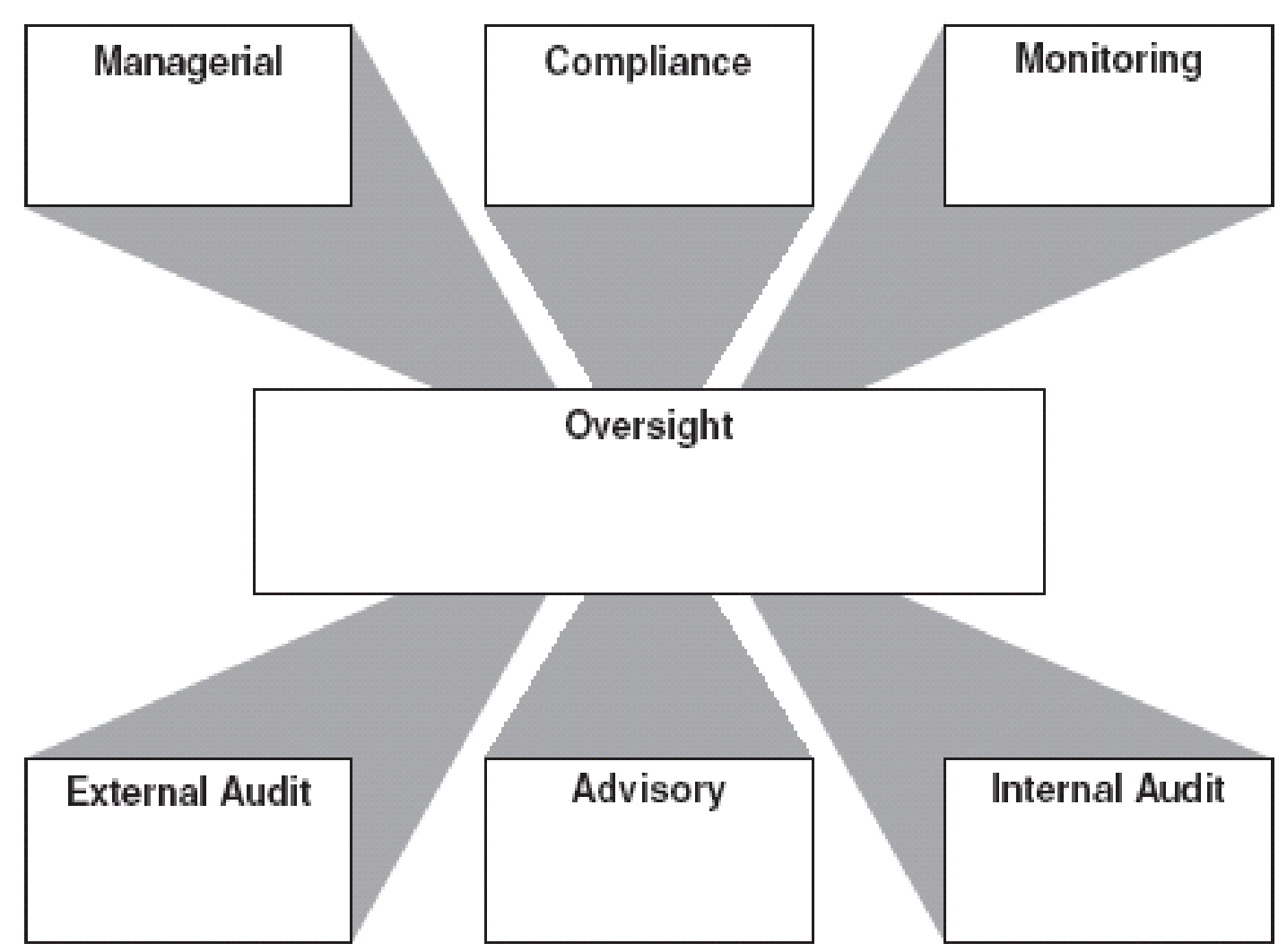

\section{THE UNIVERSITY OF MEMPHIS.}




\section{Corporate Governance Functions}

- OVERSIGHT FUNCTION. The board of directors should provide strategic advice to management and oversee managerial performance yet avoid micromanaging.

- MANAGERIAL FUNCTION. The effectiveness of this function depends on the alignment of management's interests with those of shareholders.

- COMPLIANCE FUNCTION. The set of laws, regulations, rules, standards, and best practices developed by state and federal legislators, regulators, standard-setting bodies, and professional organizations to create a compliance framework for public companies in which to operate and achieve their goals.

- INTERNAL AUDIT FUNCTION. Assurance and consulting services to the company in the areas of operational efficiency, risk management, internal controls, financial reporting, and governance processes.

- LEGAL AND FINANCIAL ADVISORY FUNCTIONS. Legal advice and assists the company, its directors, officers, and employees in complying with applicable laws and other legal obligations and fiduciary duties.

- EXTERNAL AUDIT FUNCTION. External auditors lend credibility to the company's financial reports and thus add value to its corporate governance through their integrated audit of both internal control over financial reporting and financial statements.

- MONITORING FUNCTION. Shareholders, particularly institutional shareholders, empowered to elect and, if warranted, remove directors. 


\section{Ethics Triangle}

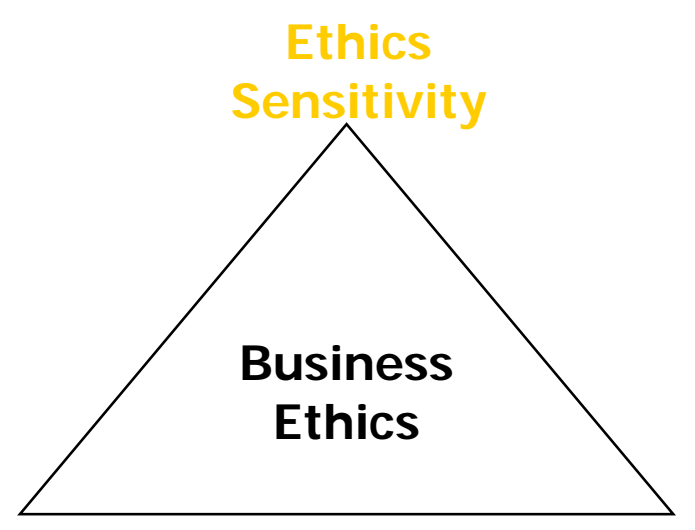

Ethical

Behavior
Ethics

I ncentives

Ethics sensitivity: Moral principles, workplace environment, gamesmanship,

loyalty, peer pressure, and job security that influence one's ethical decisions.

Ethics incentives: Rewards, punishments, and requirements for ethical behavior (e.g., tone at the top, AICPA code of professional ethics).

Ethics behavior: Doing "the right thing" rises above a rules-based mindset that asks, "is this legal," and adopts a more principles-based approach that asks, "is this right?" 


\section{Why People Commit Fraud/Corruption}

Studies show that:

1. $5-10 \%$ of people are always honest (e.g., Mother Teresa), 1-10\% are always dishonest (e.g., criminals), and the rest, $80-90 \%$ are in between.

2. This majority $80-90 \%$ are likely to commit fraud/corruption when four conditions exist:

-PRESSURE/INCENTIVES

-OPPORTUNITY/CAPABILITY

-RATIONALIZATION/ JUSTIFICATION

-LACK OF MORAL PRINCIPLES/ETHICS 
- + Absolute Power

\section{Corruption/Fraud}

- +Capability

- +Pressure/Incentives

- +Opportunity

- +Collusion

- +Greed

- +Incompetency

- -Ethical Principles and Behavior

- -Effective, Efficient and Scalable Regulations

- -Compliance/Enforcement

- -Corporate Governance

- -Accountability 


\section{Concluding Remarks}

- $\quad$ The AACSB standards now require "Business Sustainability, Corporate Governance, and Organizational Ethics" education for business schools starting January 2019.

- Business sustainability is now being integrated into corporate culture and strategic decisions because sustainability performance information is demanded by investors, required by global regulators, more than 45000 business organizations are now disclosing sustainability information worldwide.

- Sustainability is also integrated into all disciplines in business colleges from management, accounting, supply chain, marketing, economics, finance and BIT and more than 450 business programs offer a stand-alone business sustainability course.

- Business sustainability, corporate governance and professional ethics are taking center stage in the global business environment.

- $\quad$ Corporate governance has been the main theme of the $21^{\text {st }}$ century and business sustainability is transforming from branding and greenwashing to a business strategic imperative.

- Organizational ethics has been promoted in improving and promoting corporate culture of integrity, competency and accountability and preventing future financial scandals and crises. 


\section{M}

\section{THE UNIVERSITY OF}

Integrating Business Sustainability, Corporate Governance and Organizational Ethics into Business and Accounting Curricula

AAA Annual Meeting 2020

Damon M Fleming, PhD, CFA 


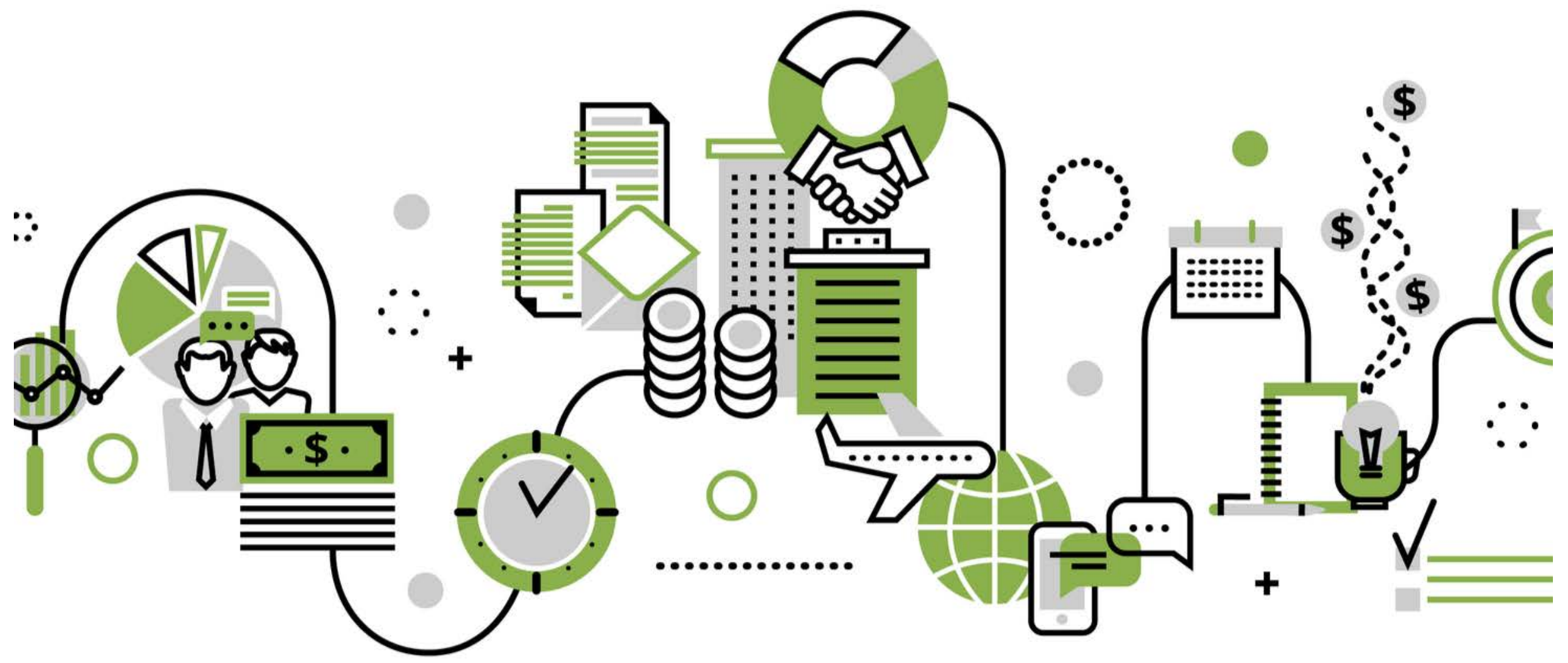


- Climate change risks

Environmental accidents and remediation

- Water use and management

- Energy management

- Fuel management and transportation

- GHG emissions and air pollution

- Waste management and effluents

- Biodiversity impacts

- Communications and engagement

- Community development

- Impact from facilities

- Customer satisfaction

- Customer health and safety

- Disclosure and labeling

- Marketing and ethical

advertising

- Access to services

- Customer privacy

- New markets

\section{- Diversity and equal}

5) opportunity

- Training and development

- Recruitment and retention

- Compensation and benefits

- Labor relations and union practices

- Employee health, safety and wellness

- Child and forced labor
4.
1.

ENVIRONMENT LEADERSHIP \&
GOVERNANCE

\section{GOVERNANCE}

BUSINESS

MODEL \&

INNOVATION
SOCIAL

OF

UNIVERSE

ESG ISSUES challenges

Long term viability of core business

- Accounting for externalities

Research, development and

innovation

- Product societal value

- Product life cycle use impact

- Packaging

- Product pricing

- Product quality and safety

conduct

Business ethics and

competitive behavior

Shareholder engagement

Board structure and

independence

- Executive compensation

- Lobbying and political

contributions

Raw material demand

- Supply chain standards and selection

- Supply chain engagement 8 transparency 


\section{UNIVERSE OF SUSTAINABILITY ISSUES}

Environmental Capital | Social Capital | Human Capital | Business Model \& Innovation | Leadership \& Governance

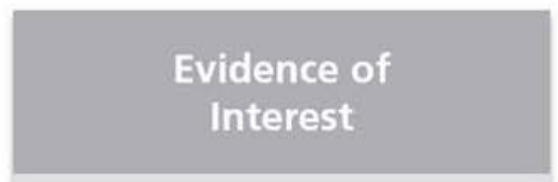

Issue frequency in 5 data-driven tests:

- Financial risks

- Legal drivers

- Industry norms

- Stakeholder concerns

- Innovation opportunity
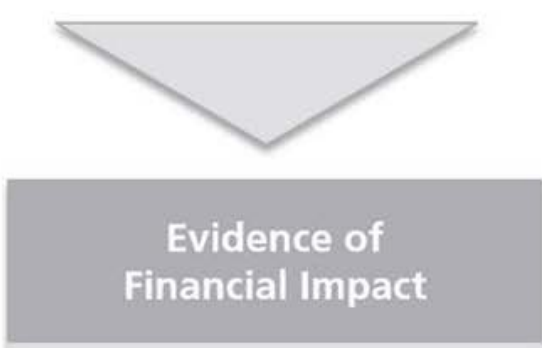

Issue impact on 4 business value drivers:

- Revenue impact

- Return on capital

- Risk management

- Management quality

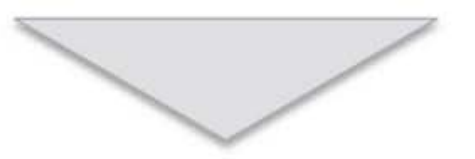

\section{Forward-looking} Adjustment

Issue relation to 3 sustainability principles:

- Magnitude

- Probability

- Externalities

\section{PRIORITIZED SUSTAINABILITY ISSUES}

\section{THE UNIVERSITY OF MEMPHIS.}




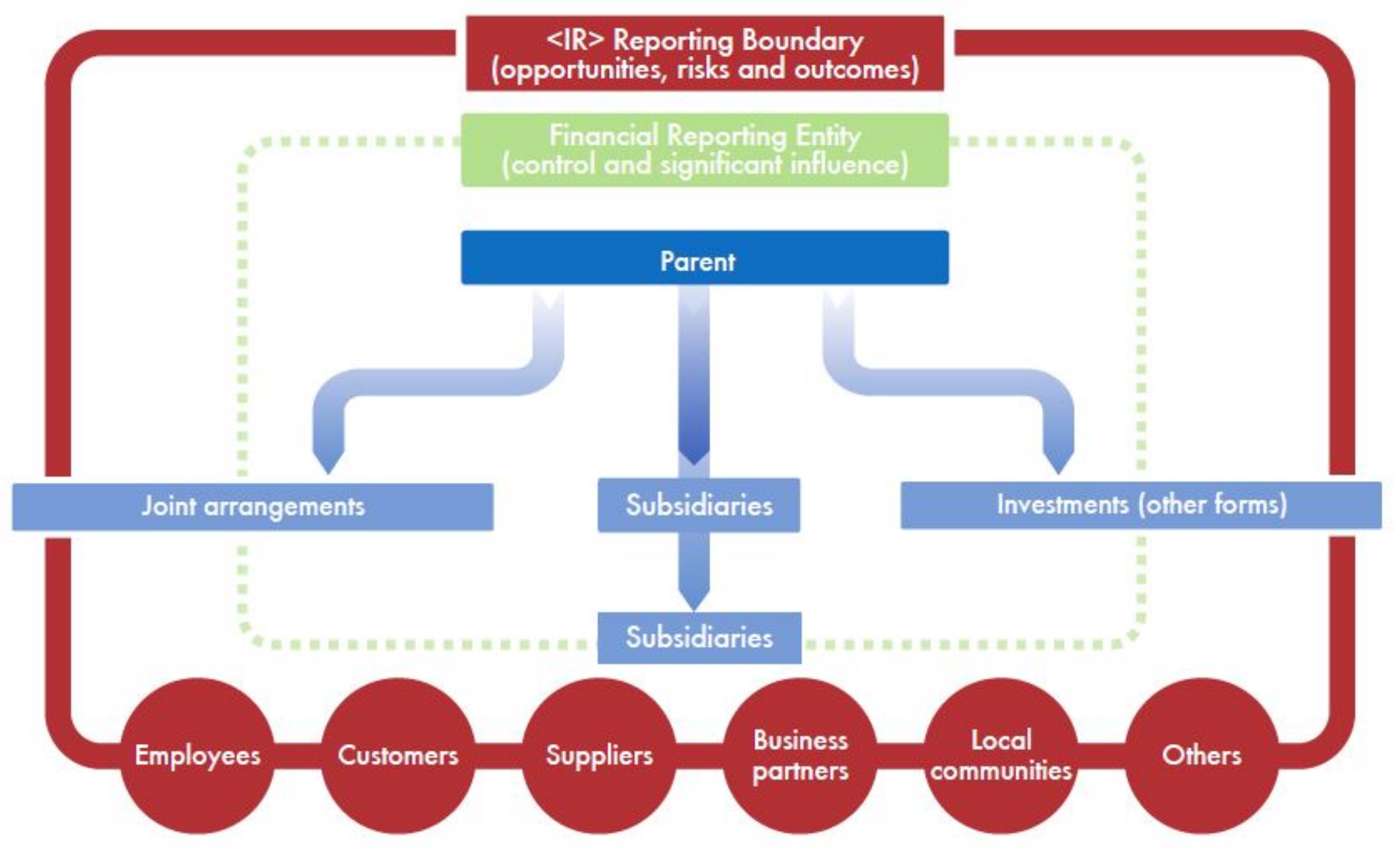

THE UNIVERSITY OF MEMPHIS. 


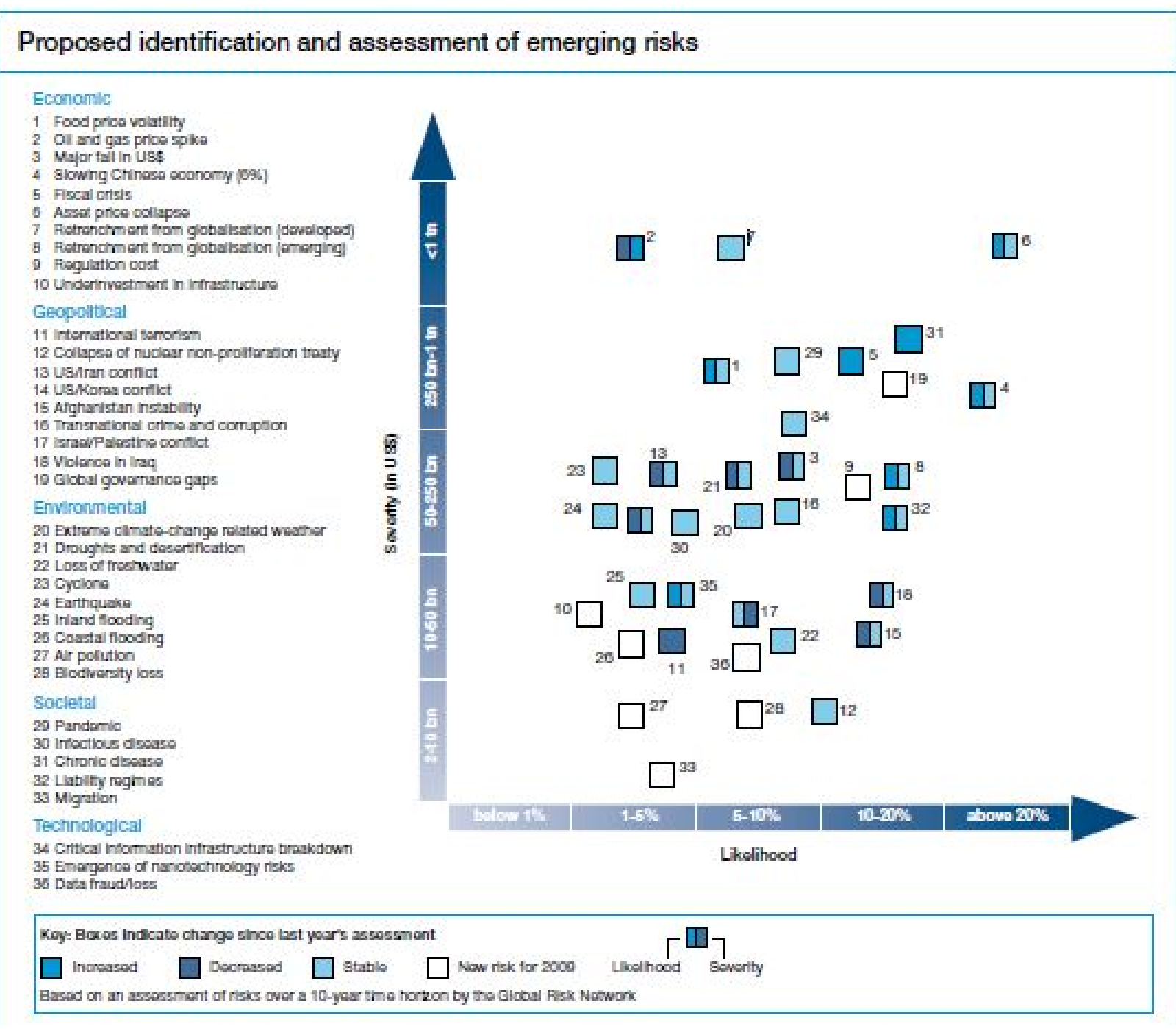

\section{THE UNIVERSITY OF MEMPHIS.}




\section{Top of Mind}

- Limited coverage of sustainability reporting and integrated reporting in business school curricula

- $\quad$ Risks, scope, measurement, best practices, and reporting standards remain challenges

- Demand for disclosure and reporting (companies and financial markets)

- Growing demand for consulting and assurance services, yet limited supply 


\section{Business Sustainability In Practice}

Robert B. Hirth, J r.

Senior Managing Director

Protiviti and a Vice Chair

Board of the Sustainability

Accounting Standards Board

(SASB) 


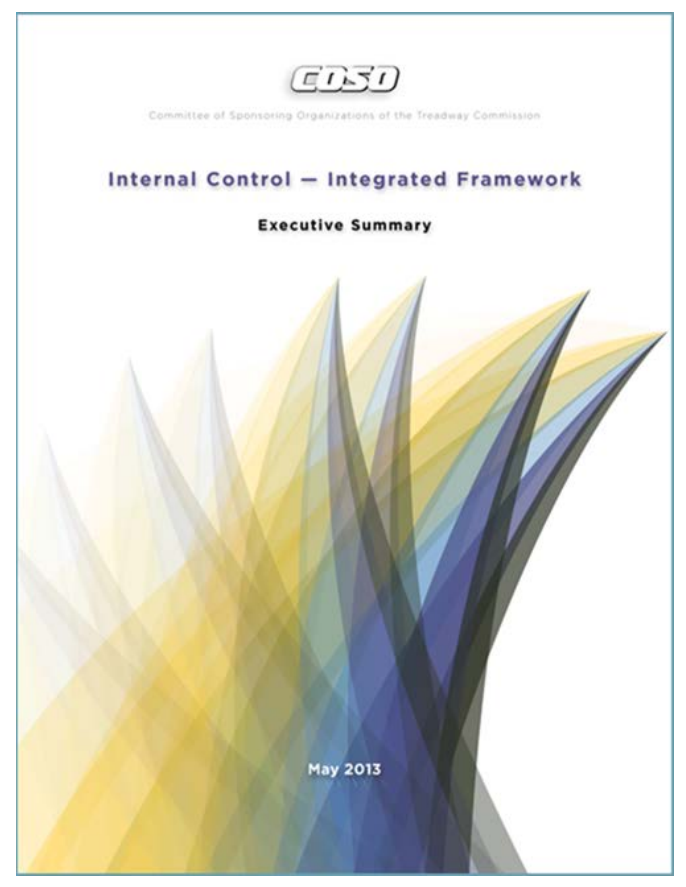

\section{protiviti $^{\circ}$}

Face the Future with Confidence

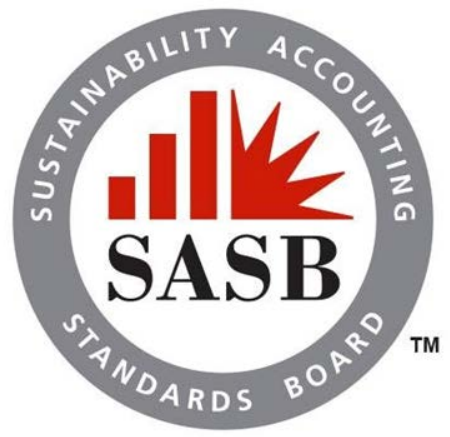

THE UNIVERSITY OF MEMPHIS 


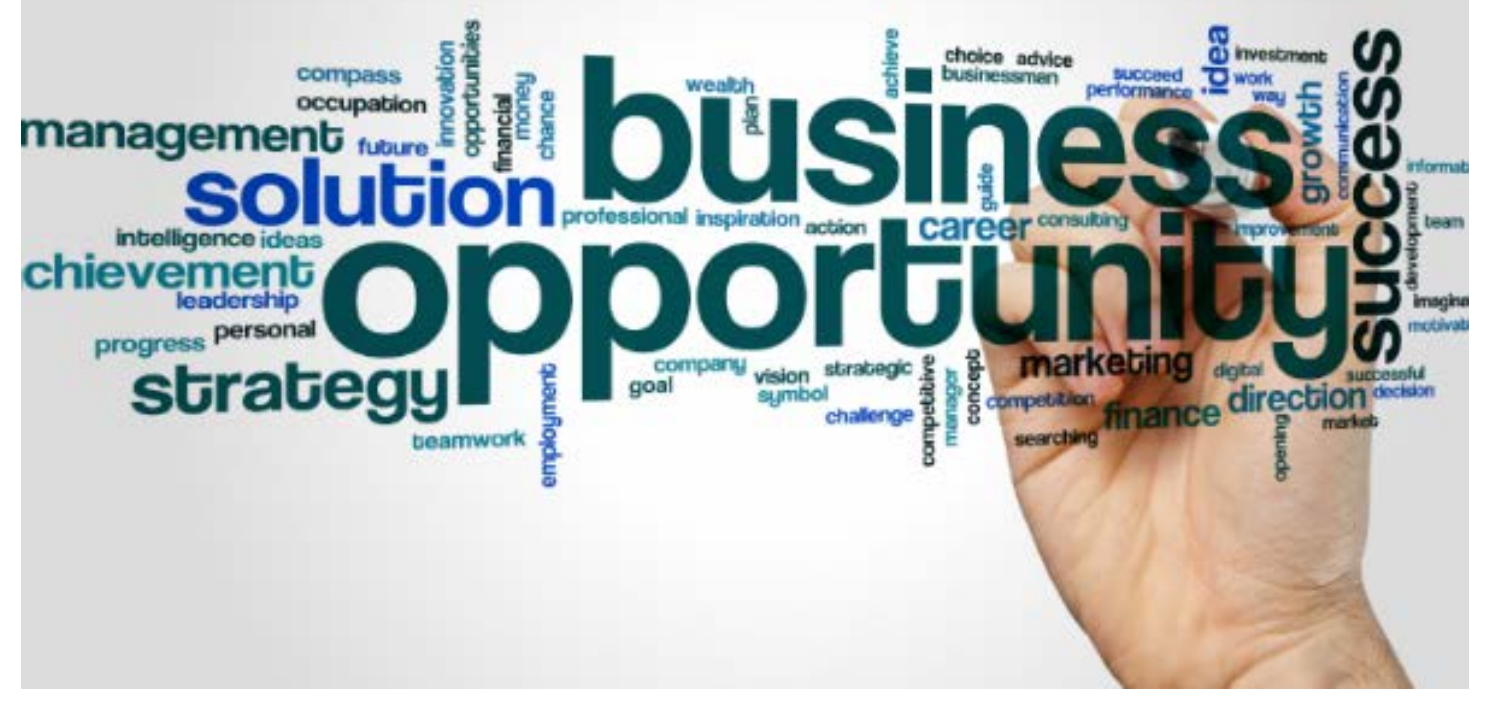




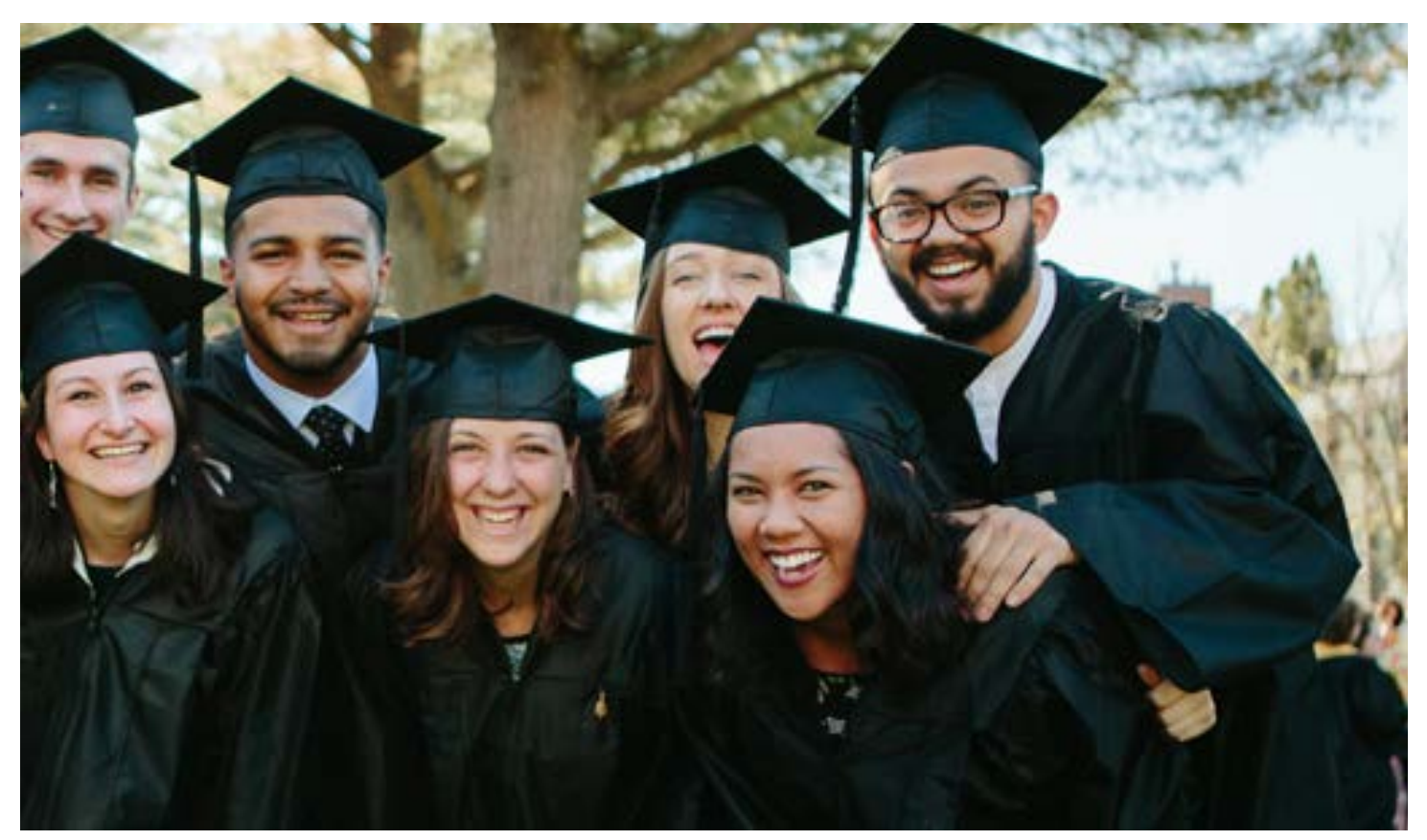

THE UNIVERSITY OF MEMPHIS. 


\section{0\% of S\&P 500 Publish ESG/Sustainability Reports (Source: G\&A Institute)}

2011 2012 2013 2014 2015 2016 2017 2018 2019

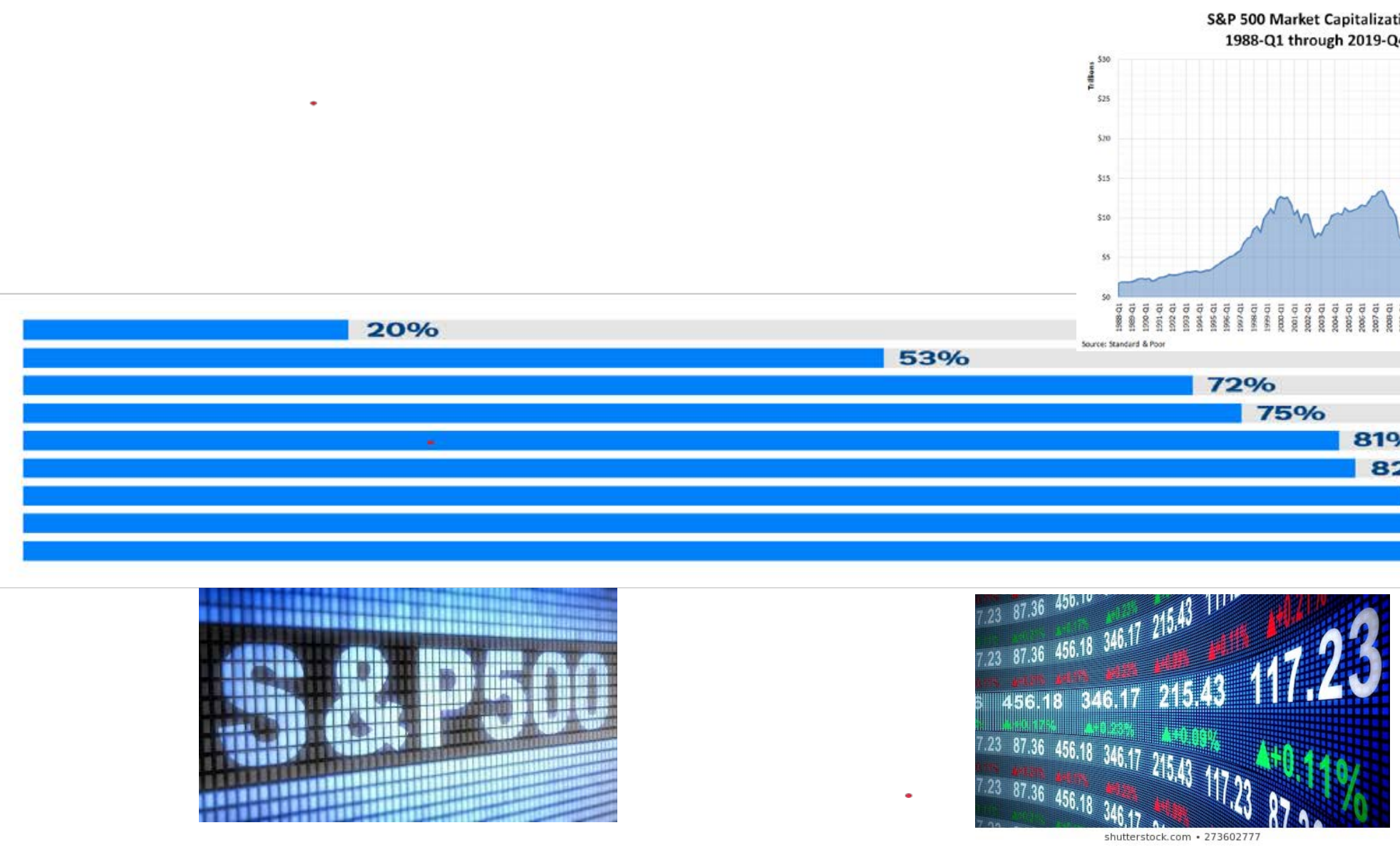




\section{A Reminder or a Requirement...?}

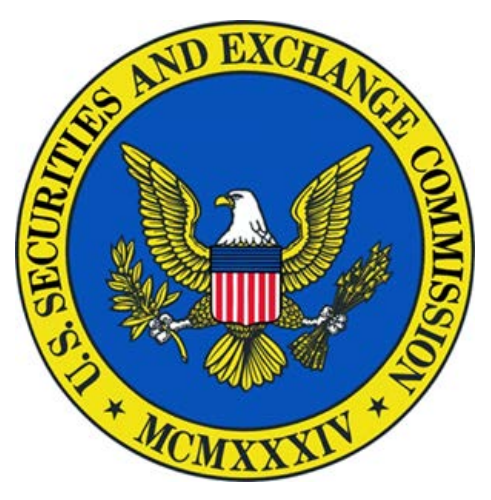

This interpretive release is intended to remind companies of their obligations under existing federal securities laws and regulations to consider climate change and its consequences as they prepare disclosure documents to be filed with us and provided to investors 


\section{The BIG NEW NEWS...}

(January 2020)

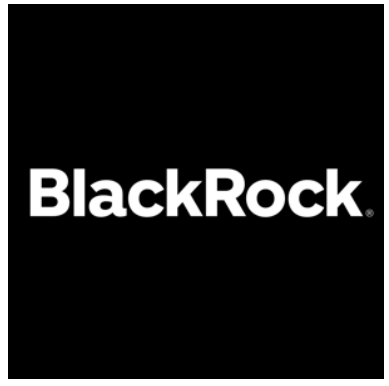

We will be increasingly disposed to vote against management and board directors when companies are not making sufficient progress on sustainability-related disclosures and the business practices and plans underlying them.

This year, we are asking the companies that we invest in on behalf of our clients to: (1) publish a disclosure in line with industry-specific SASB guidelines by year-end, if you have not already done so, or disclose a similar set of data in a way that is relevant to your particular business; and (2) disclose climate-related risks in line with the TCFD's recommendations, if you have not already done so. 
Toward Common Metrics and Consistent Reporting of Sustainable Value Creation
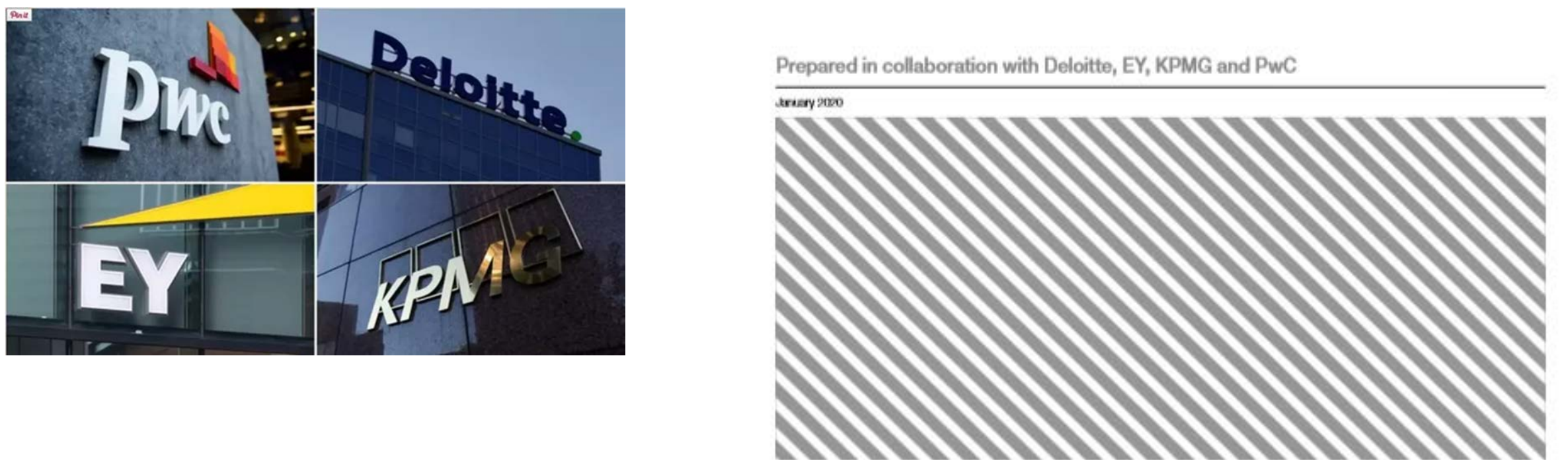

THE UNIVERSITY OF MEMPHIS. 


\section{What the Heck is SASB?}

SASB is a private initiative designed to improve the sustainability disclosures of US public companies when those sustainability matters are material. Improvement includes:

- Disclosure of ESG matters, when mate

- Specific, comparable, consistent, define

- Decision useful, investment grade

- Driven by industry participants 
Industries Grouped by Resource Intensity \& Sustainability Impacts Sustainable Industry Classification System (SICS ${ }^{\circledR}$ ): 77 industries within 11 sectors

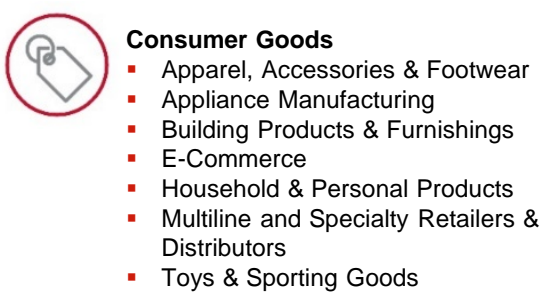

Extractives \& Minerals Processing

Coal Operations

- Construction Materials

- Iron \& Steel Producers

- Metals \& Mining

- Oil \& Gas - Exploration \& Production

- Oil \& Gas - Midstream

- Oil \& Gas - Refining \& Marketing

- Oil \& Gas - Services

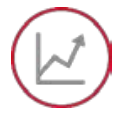

Financials

Asset Management \& Custody Activities

Commercial Banks

- Consumer Finance

- Insurance

- Investment Banking \& Brokerage

- Mortgage Finance

- Security \& Commodity Exchanges

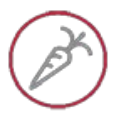

Food \& Beverage

Agricultural Products

Alcoholic Beverages

Food Retailers \& Distributors

- Meat, Poultry \& Dairy

Non-Alcoholic Beverages

- Processed Foods

Restaurants

- Tobacco

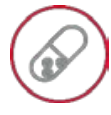

Health Care

Biotechnology \& Pharmaceuticals

Drug Retailers

Health Care Delivery

Health Care Distributors

- Managed Care

- Medical Equipment \& Supplies

\section{Infrastructure}

Electric Utilities \& Power Generators

Engineering \& Construction Services

Gas Utilities \& Distributors

Home Builders

Real Estate

Real Estate Services

Waste Management

Water Utilities \& Services

Renewable Resources \&

Alternative Energy

- Biofuels

- Forestry Management

- Fuel Cells \& Industrial Batteries

- Pulp \& Paper Products

- Solar Technology \& Project Developers

- Wind Technology \& Project Developers

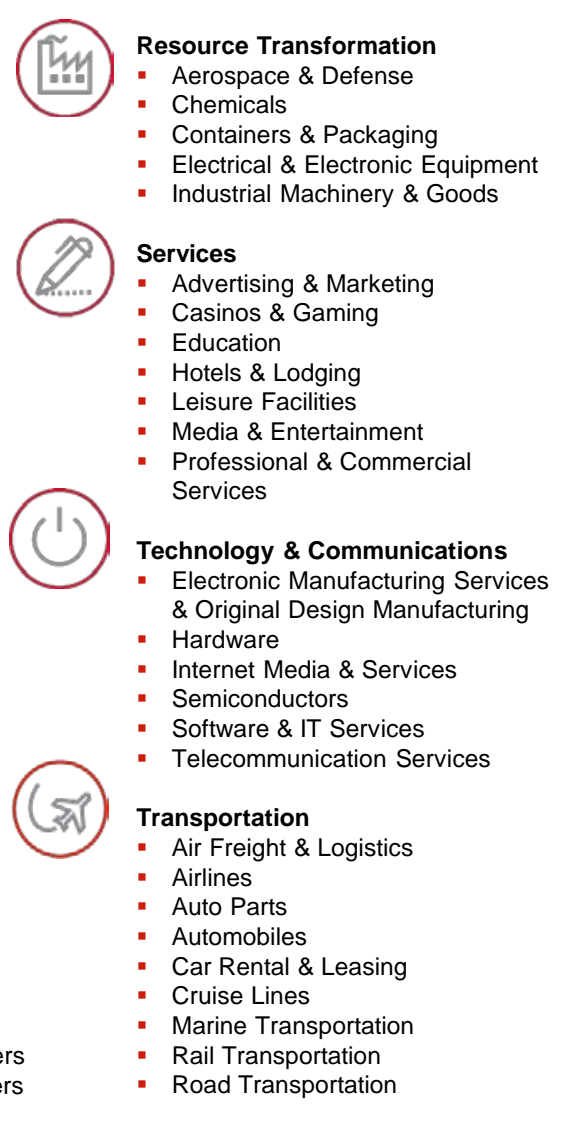




\section{Internal Control and \\ Sustainability Reportinn}

"The financial reporting objective category is expanded to consider other external reporting beyond financial reporting, as well as internal reporting, both financial and nonfinancial."

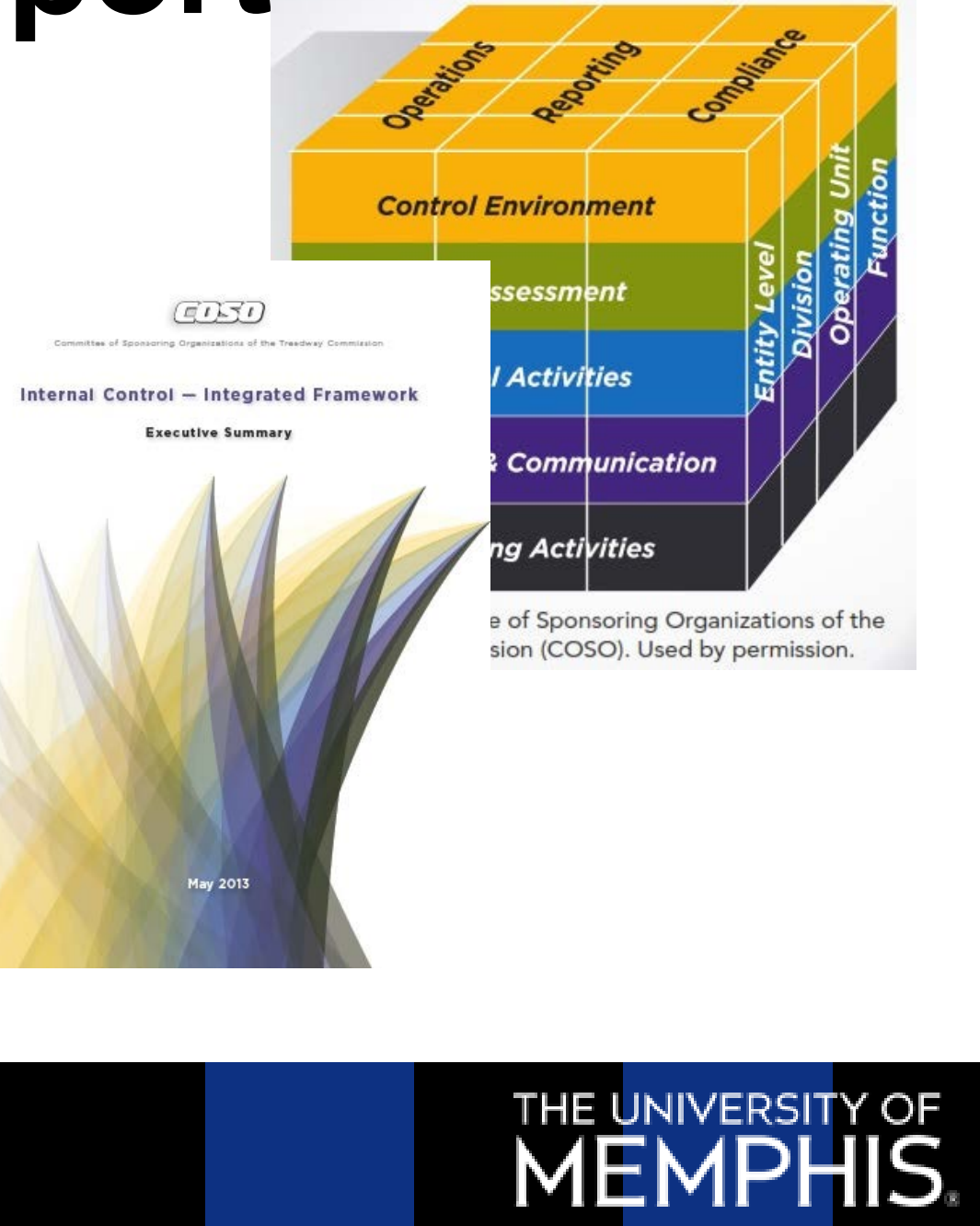




\section{Control - Integrated Framework to Improve Confidence in Sustainability Performance Data}

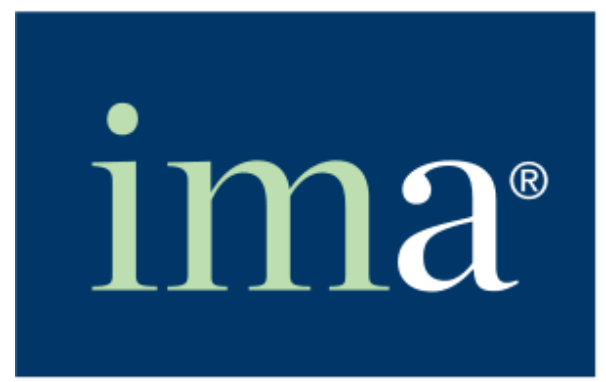

The Association of Accountants and Financial Professionals in Business

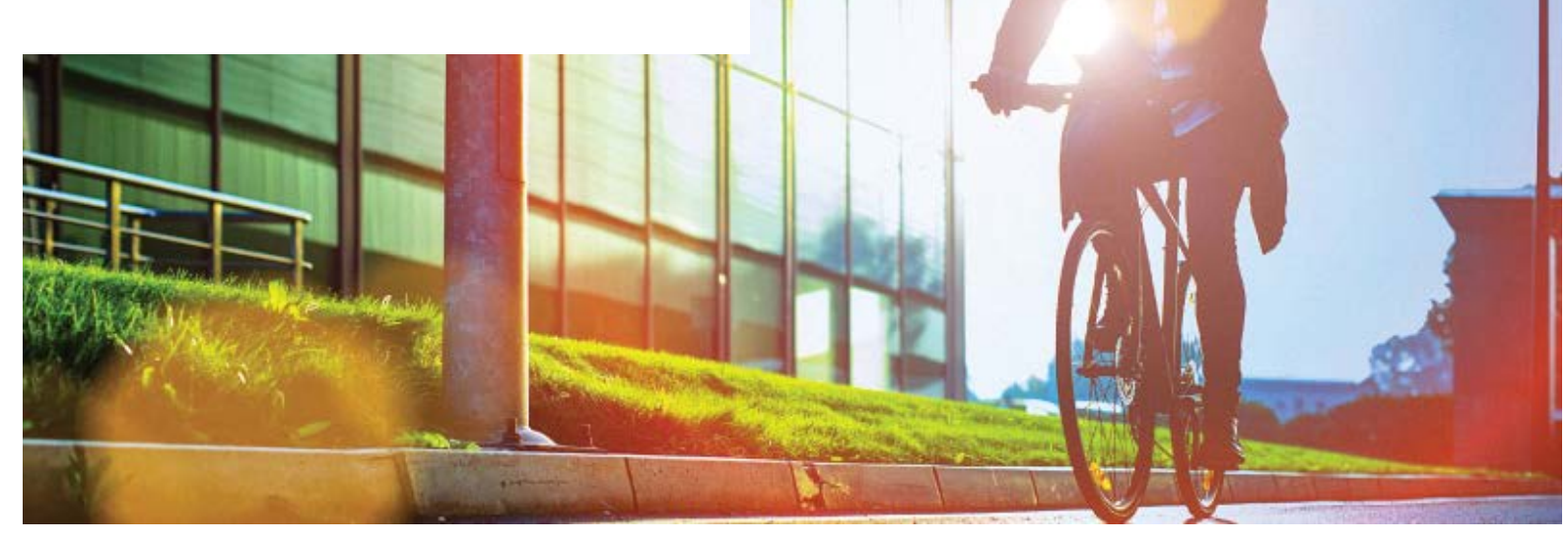
MEMPHIS. 


\section{Applying enterprise risk management to environmental, social and governance-related risks}
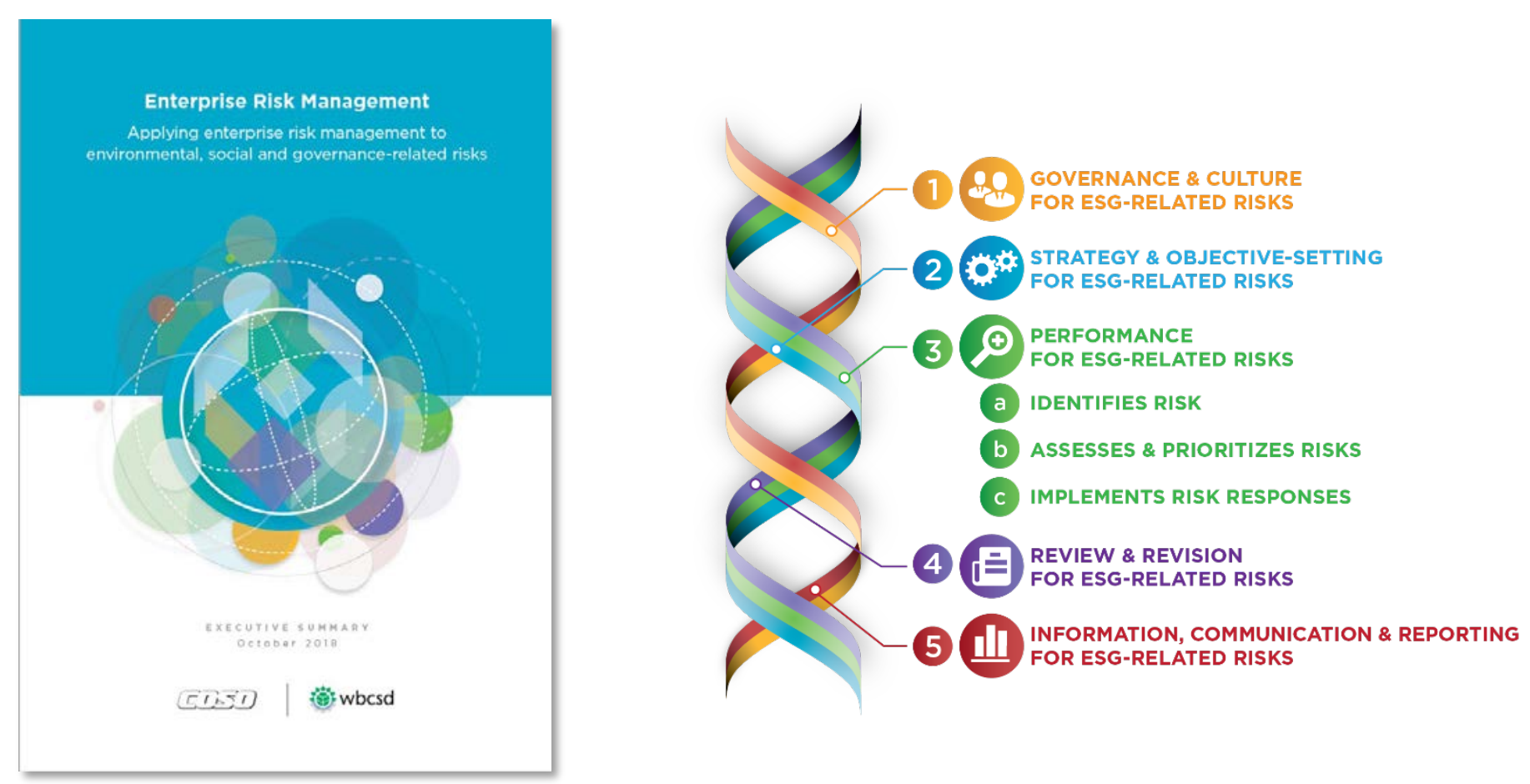

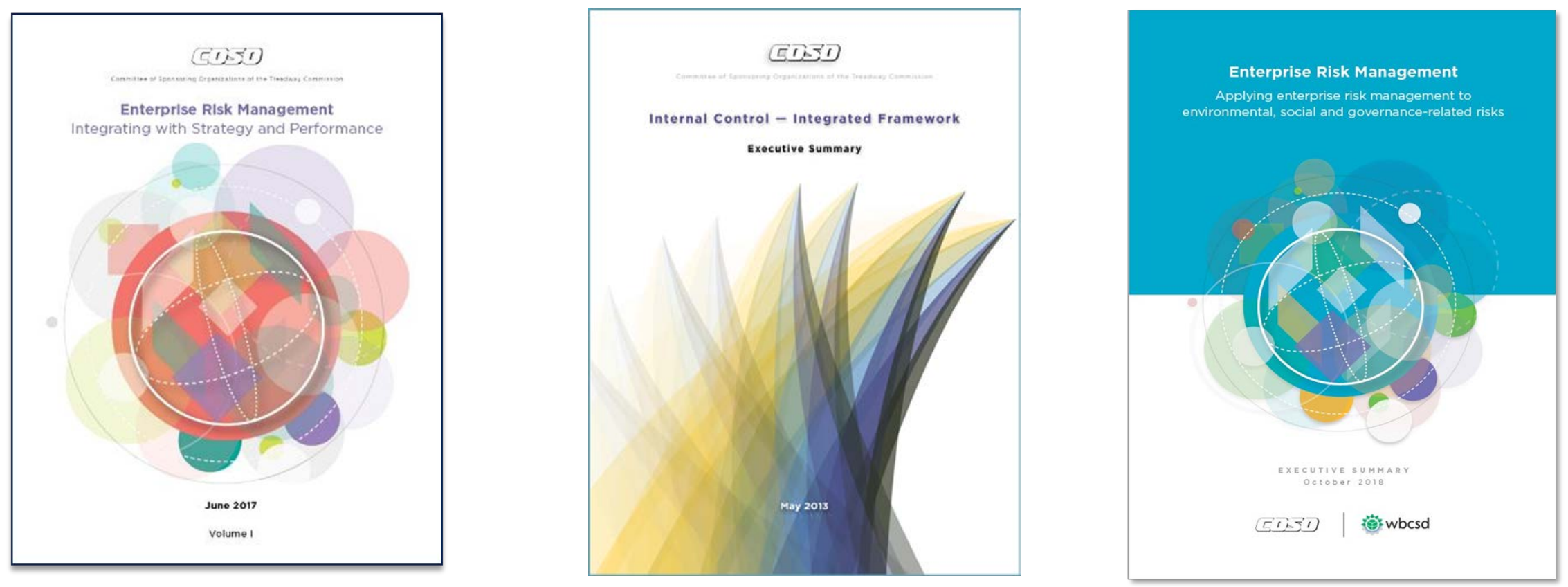

\section{THE UNIVERSITY OF MEMPHIS}




\section{Professor Sri Ramamoorti, \\ University of Dayton \\ Corporate Governance}

- BEHAVIORAL VIEW: The underlying psychological architecture and principles

- Market participants are human beings first, then they are investors, executive management, BOD members, risk and compliance managers, accountants or auditors...so the general principles of psychology and human behavior apply to them!

- Financial reporting is a form of "impression management" (cf. Goffman's "Presentation of the Self in Everyday Life," 1959; Healy \& Palepu, 2001)

- Management has an in-built bias to portray a rosy picture of the financials: window dressing, earnings management to highlight good news, suppress/delay bad news

- Auditor's goal is reducing information asymmetry risk, and exert a constraining influence on unbridled optimism (and outright fraud)

- The tension between VALUE CREATION vs. VALUE PRESERVATION 


\section{Power with Accountability}

Ultimate corporate governance problem:

\section{How to grant talented and capable} managers enormous discretionary power over the conduct of the business while holding them accountable for the use of that power?

(Monks \& Minow, on Corporate Governance, 2001) 


\section{Need for Critical Thinking}

"[B]ecause we live in an age of manipulation... armies of hucksters and demagogues stand ready with the rich resources of psychology to play upon our emotions and subconscious needs to persuade us that superficial is profound, harmful is beneficial, evil is virtuous. And feelings are especially vulnerable to such manipulation... in virtually every important area of modern life-law, medicine, business, and community affairs - we are beset with serious problems and complex issues that demand careful gathering and weighing of facts and informed opinions, thoughtful consideration of various conclusions or actions, and judicious selection of the best conclusion or most appropriate action."

--V. R. Ruggiero, 1995 in his preface to Beyond Feelings: A Guide to Critical Thinking +22 years later $=$ fake news! So, professional skepticism is a highly desirable trait 


\section{ON GREENWASHING}

"disinformation disseminated by an organization so as to present an environmentally responsible public image."

Accountantspeak: "Form over substance"

Examples: Volkswagen, FB/CA, Wells Fargo

Accountability metrics: KPIs and KRIs 


\section{GOOD AND BAD TIMES}

Corporate governance in good times differs remarkably from that during bad times

Bad times $=$ crisis!

Requires very different skillsets and competencies from BOD

COVID-19 has exposed this vulnerability; may organizations may not survive, others may completely overhaul their "unfit" BOD

Sustainability governance: a critical consideration 


\section{Sustainability Accounting}

- Accounting for Sustainability is the desperate need of the hour

- If accountants do not step up to the plate, our entire profession will be seen as "enablers" for capitalism that has lost its way

- Business Roundtable Principles from August 2019: shared prosperity and sustainability for business and society

- Accounting for sustainability may well ensure the sustainability of accounting! 


\section{Corporate Governance - Data Brigitte Muehlmann Babson College}




\section{ESG or GSE? Event and erosion risks}

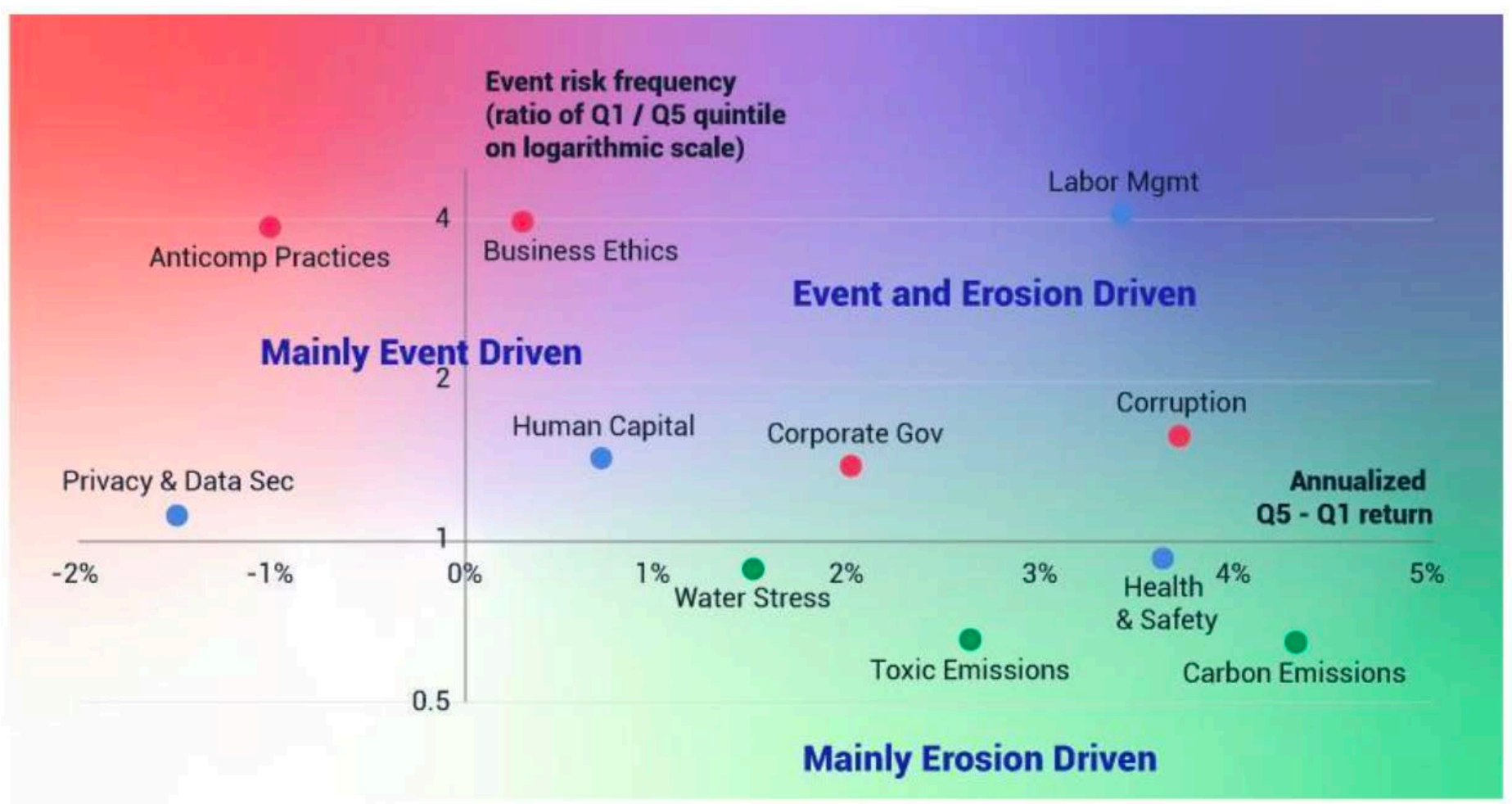




\section{Disclosure examples}

\section{ESG Index verizon $\sqrt{ }$}
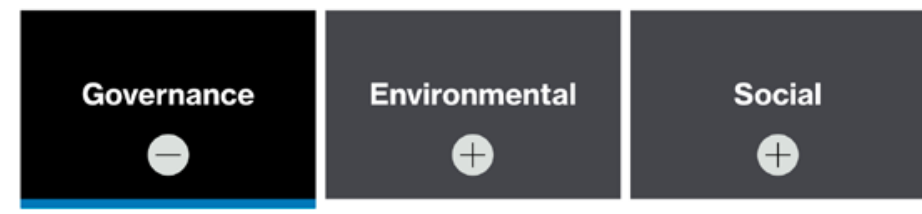

2019

Board

disclosures

started

\section{Board diversity}

Percentage of women on the Board of Directors

Percentage of African-American and Hispanic individuals on the Board of
Directors

\section{ESG Data Center}

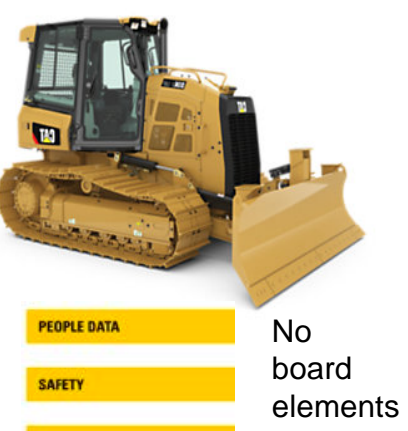

ENERGY-OPERATIONS

EMISSIONS - OPERATIONS

WATER - OPERATIONS

WASTE- OPERATIONS

PRooucrs

MatenuLL

REMANUFACTURING

SUSTAINABLE CONSTRUCTION

PHILANTHROPY

This data table reports indicators Entergy considers to be important to the company and its stakeholders, and to measure its sustainability. This data is from Entergy's

iwo primary business units: Utilities and EWC. It is based on $100 \%$ operational control in all cases except for air emissions which are reported on an equity basis. Additional data and information can be found in our online GRI matrix located at https://www.entergy.com/sustainability.

AS-REPORTED FINANCIAL HIGHUGHTS Operating revenues (\$ millions)

Net income attributable to Entergy Corp. (\$ millions)

Earnings per diluted share (dollars)

Total shareholder return (\%)

Utility retail customers - year-end (thousands)

2015

Goveruance a tirics

Number of independent Board Directors

Women/minority independent Board Directors (number; \%)

EMPLOVEES

\begin{tabular}{r|r} 
& \multicolumn{2}{|c|}{2016} \\
\hline 11,513 & 10,8 \\
-177 & -5 \\
-0.99 & -3 \\
-18.2 & 12 \\
\hline 2,800 & 2,900 \\
\hline
\end{tabular}

\begin{tabular}{|r|r|r|r|} 
& \multicolumn{2}{|c|}{2017} & \multicolumn{2}{c|}{2018} & \multicolumn{1}{c|}{2019} \\
\hline-584 & 11,074 & 11,009 & 10,879 \\
\hline 3.26 & 412 & 849 & 1,241 \\
\hline 12.5 & 2.28 & 4.63 & 6.30 \\
\hline 900 & 15.9 & 10.6 & 44.3 \\
\hline
\end{tabular}

\begin{tabular}{r|r|r|r|r|}
\hline 13 & 11 & 11 & 10 & 10 \\
\hline 12 & 10 & 10 & 9 & 9 \\
\hline
\end{tabular}
4; $36 \%$ 4; 36\% 4; $40 \%$ $4 ; 40 \%$ 


\section{On the horizon:}

- Overboarded directors, not enough bandwidth during the event-driven pandemics. E.g.:

CEO - number of outside directorships

non-CEO director - number of public company boards, number of committee chairs

- Director-shareholder engagement, without the buffer of management.

E.g.:

Engagement with shareholders by number, percentage, or asset base Engagement with proxy advisors 


\section{Organizational Ethics}

Timothy Fogarty, Professor of Accounting at Case Western Reserve University 


\section{Organizational Ethics}

- Ethics: drives from a combination of the individual and/or family values, moral principles, religious believes, cultural norms and best practices. Values are inspired, celebrated and championed. They have to come from moms and dads, teachers and preachers.

- Business Ethics: The moral principles and ethical standards that guide business behavior. The collective values of a business organization that can be used to evaluate whether the behavior of the collective members of the organization are considered acceptable and appropriate.

- Professional Ethics: A learning process of professional values, ethics, codes of conduct and accountability to act in the best interest of the profession, the public and the global society. 


\section{Questions?}

\section{Thank you for your attention!}

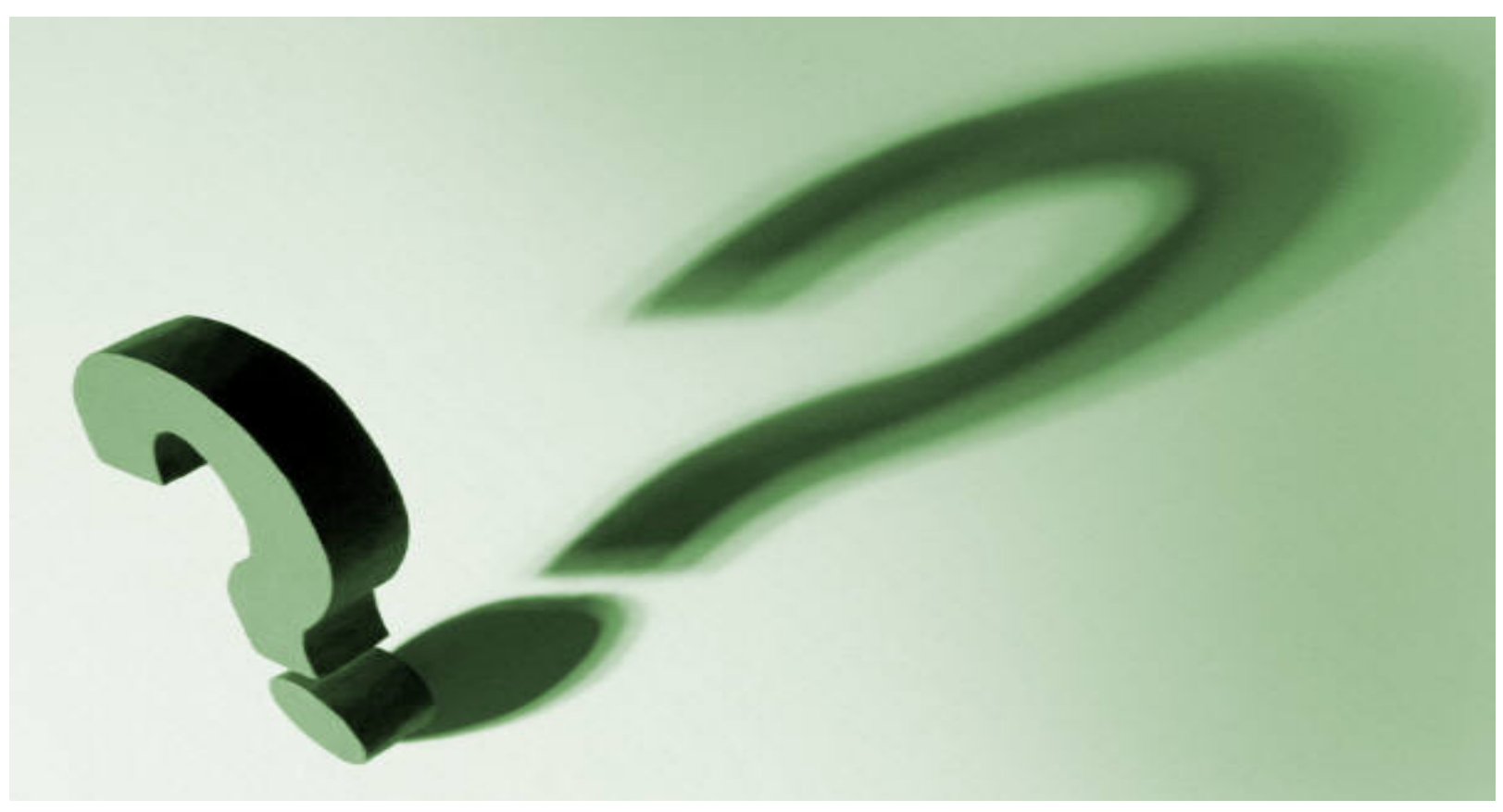

